năng phát hiện theo dõi các bất thường và tầm soát sớm bệnh lý ung thư cổ tử cung.

\section{KẾT LUẦN}

Xét nghiệm tế bào cổ tử cung và xét nghiệm HPV trong 1450 bệnh nhân đến khám tại bệnh viện $\mathrm{K}$ từ tháng 12/2019 đến tháng 10/2020 cho kết quả như sau: Tỉ lệ dương tính HPV trong mẫu nguyên cứu là $11,2 \%$.

Tỉ lệ tế bào cổ tử cung bất thường là 3.9\% và tỉ lệ bệnh nhân có giải phẫu bệnh bất thường 1.9\%.

Tỉ lệ nhiễm HPV trong các trường hợp ASCUS là 15\%, ASC-H 14,2\%, LSIL 67\% AGUS 67\% HSIL 92.8\% Carcinoma 100\%. Mức độ bất thường càng nặng, tỷ lệ nhiễm HPV nguy cơ cao càng cao.

\section{TÀI LIỆU THAM KHẢO}

1. Bùi Diêu, Vũ Thị Hoàng Lan và công sứ, (2010), "Tình hình nhiếm HPV tại Hà Nội", Tạp chí Y học thực hành- Bộ Y tế, số 745- số 12/2010, tr. 5- 6

2. Nguyễn Phi Hùng, Nguyễn Thị Lan Anh, Tại Văn Tờ, Nguyển Văn Chư, (2011), "Nghiên cứu xác định các týp HPV thường gặp trong ung thư cổ tử cung", Y hơc Thành phố Hồ Chí Minh, Chuyên đề giải phâuu bệnh, tập 15 (2), tr. 160- 167.

3. Cao Thị Kim Chúc, (2009), Tình hình nhiễm Human Papilloma virus trên bênh nhân đến khám bệnh lây truyền qua đường tình dục tại Bệnh viện Da Liễu Hà Nội (1.2008- 10.2008), Luận văn Thạc sĩ Y hợc, Trường Đại học Y Hà Nội

4. Nguyê̂n Đức Hinh, Ngô Văn Toàn, Lưu Thì Hống, Lê Duy Toàn, Nghiêm Xuân Hanh và cộng sự, (2015), "Mối liê̂n quan giữa nhiểm HPV nguy cớ cao và ung thư cổ tứ cung tại Việt Nam", Tạp chí Phụ Sản, Tập 13, (2), tr. 06-08.

5. Nguyến Phi Hùng, Nguyến Thị Lan Anh, Tai Vằn Tờ, Nguyễn Văn Chủ, (2011), "Nghiên cứu xác định các týp HPV thường găp trong ung thư cổ tử cung", Y hoc Thành phổ Hồ Chí Minh, Chuyên đề giải phẫu bệnh, tập 15 (2), tr. 160- 167.

6. Cung Thị Thu Thủy, Hồ Thị Phương Thảo, (2012), "Nghiên cứu kết quả soi cổ tử cung ớ những bệnh nhân có tế bào âm đạo- cổ tử cung bất thường nhiếm Human Papilloma virus tai Bênh viện Phụ Sản Trung ương", Tạp chí Phụ Sản, tập 10 , số 2, tr. 152-157.

\title{
BÁo CÁO CA LÂM SÀNG CHẢY DİCH NÃO TỦY QUA MŨI TÁI PHÁT NHIỀU LẦN
}

\section{TÓM TẮT}

Nhân một bệnh nhân nữ 40 tuổi sau PTNSM chảy dịch não tủy kéo dài và tái phát nhiểu lần. Bệnh nhân được phẫu thuật bít rò dịch não tủy 4 lần, nhưng vẫn khồng cải thiện. Trường hợp chảy DNT tái phát nhiều lần không tương xứng với nguyên nhân được biết trước đó có thể do tồn tại một yếu tố khác chưa kịp nhận diện, bệnh nhân này được xác định carcinoma tế bào gai biệt hóa trung bình. Bệnh nhân được điều trị phẫu thuật cắt bỏ khối u qua nội soi mũi và phẫu thuâtt tái tạo nền so trước bằng kỹ thuâtt nhiều lớp sử dụng 2 vạt có cuốn cải tiến, sau phẫu thuật tiếp tục xạ trị phối hợp. Hiện tại bệnh nhân ổn định và hết tình trạng chảy dịch não tủy. Như vậy, để điều trị những trường hợp chảy dịch não tủy tái phát nhiều lần sau phẫu thuật, cần tìm những nguyên nhân tiềm ẩn và sử dụng phương pháp tái tạo nền sọ cải tiến như một lựa chọn.

Tư khóa: chảy dịch não tủy tái phát, chảy dịch não tủy khó, khuyết sàn sọ trước rộng, kỹ thuật tái tạo nền sọ trước nhiều lớp có sử dụng 2 vạt có cuốn.

*Bệnh viện Chợ Rẫy

Chịu trách nhiệm chính: Ngô Văn Công

Email: congtmh@gmail.com

Ngày nhận bài: 21.9.2021

Ngày phản biện khoa học: 15.11.2021

Ngày duyệt bài: 23.11.2021
Ngô Văn Công*

\section{SUMMARY \\ PERSISTENT CEREBROSPINAL FLUID RHINORRHOEA FOLLOWING MISDIAGNOSIS OF MALIGNANT TUMOR - A CASE REPORT}

A 40-year-old female patient presented with recurrent cerebrospinal fluid (CSF) rhinorrhoea following an endoscopic sinus surgery (ESS). The patient underwent four further unsuccessful CSF leak repairs. In the case of persistent CSF rhinorrhoea that was uncorrelated with the previously known cause, there could be unrecognized factors. The patient was then diagnosed with moderately differentiated squamous cell carcinoma of nasal cavity. Treatment was conducted by a combination of endoscopic resection of the tumor and anterior skull base reconstruction surgery. The defect was reconstructed with a multilayered technique using 2 pedicled flaps. Postsurgical radiotherapy was then performed. At follow-up, recurrent CSF leak did not occur. Therefore, in case of persistent CSF rhinorrhoea following an ESS, it is necessary to identify underlying causes. Performing a modified technique of skull base reconstruction is an option to successfully manage such cases.

Keywords: recurrent cerebrospinal fluid rhinorrhoea, persistent cerebrospinal fluid rhinorrhoea, large skull base defects, multilayered reconstruction technique using 2 pedicled flaps.

\section{GIỚI THIỆU}

Nguyên nhân chảy dịch não tủy (DNT) qua 
mũi thường gặp nhất là chấn thương (do tai nạn hay do điều trị). Tuy nhiên một bệnh nhân có thể có nhiều yếu tố căn nguyền khác nhau. Vì vậy đối với những trường hợp chảy DNT qua mũi tái phát nhiều lần dù đã được điều trị phù hợp, có thể còn có nguyên nhân tiềm ẩn khác [4]. Lâm sàng, sinh hóa và hình ảnh học cần thiết giúp xác định chẩn đoán. Ở những khuyết tổn sàn sọ lớn, phấu thuật vá sàn sọ nhiều lớp kết hợp cho hiệu quả cao hơn [1],[3]. Chúng tôi xin báo cáo về một trường hợp dò DNT đã được phẫu thuật vá sàn sọ nhiêu lần cả bằng nội soi và mở sọ trán để vá sàn sọ trước nhưng vẩn tái phát. Báo cáo này sẽ tập trung vào tiên căn của bệnh nhân các biểu hiện lâm sàng, các xét nghiệm chẩn đoán và phương pháp điều trị trường hợp rò dịch não tủy khó và tái phát.

\section{CA LÂM SÀNG}

Một bệnh nhân nữ 40 tuổi trải qua phẫu thuật nội soi mũi xoang với chẩn đoán viêm xoang mạn tính tại một Bệnh viện chuyên khoa cách đây 5 năm. Sau phẫu thuật bệnh nhân thây chảy dịch trong qua mũi trái từng đợt, không giảm, nhiều hơn khi cúi người về phía trước, khi hoạt động mạnh hay khi ho. Dịch trong suốt, vị mặn, đổi khi đi kèm cảm giác đau đầu. Bệnh nhân được xác định chẩn đoán dò DNT sau phẫu thuật nội và chụp $C T$ scan xác định vị trí dò. Trong vòng 5 năm, bệnh nhân trải qua tổng cộng 4 lần phẫu thuật vá sàn sọ. Gồm 2 lần qua nội soi bởi bác sĩ tai mũi họng bằng nội soi qua mũi với kỹ thuật underlay bằng mở và vạt tại chổ, và 2 lần mổ hở bởi bác sĩ ngoại thần kinh ở các bênh viện khác nhau. CT scan thời điểm trước phẩu thuật vá sàn sọ lần thứ 4 cho thấy hình ảnh khuyết xương lớn vùng mảnh sàng và hố sàng bên trái, đậm độ dịch tại vùng sàng và xoang bướm $(T)$, thay đổi cấu trúc hốc mũi xoang hàm sàng $(T)$ sau phẫu thuật trước đó. MRI cùng thời điểm cho thấy dò DNT qua sàn sọ tại chố khuyết và DNT dò vào trong xoang bướm $(T)$, không có hình ảnh tăng áp lực nội sọ và thoát vị não (Hình 1a, 1b).

Một năm sau phẫu thuật vá sàn sọ lần thứ 4 (mở sọ trán hở), bệnh nhân đến với chúng tôi với triệu chứng chảy dịch mũi trong lẫn máu, kèm đau đâu. Dịch ở mũi cũng được xác định có sự hiện diện của DNT. Vị trí khuyết tổn sàn sọ được xác địinh bằng $\mathrm{CT}$ scan. $\mathrm{CT}$ scan cho thấy đường mổ sọ trán 2 bên, đậm độ mô mềm trong hốc mũi được phân biệt giữa máu đông và tổn thương choán chỗ, thấy được hình ảnh mất liên tục xương sàn sọ và miếng titan của lần phẫu thuật trước không che kín khuyết tổn (Hình 2). Hội chẩn giữa khoa tai mũi họng và ngoại thần kinh, quyết định phẫu thuật kết hợp nội soi và mở sọ trán ở. Thực hiện vá sàn sọ nhiều lớp với kỹ thuật cải tiến, gồm các lớp: titan, cân cơ tứ đầu đừi, vạt cuốn mũi dưới - vách mũi xoang, keo sinh học, spongel hỗ trợ. Kết quả giải phẫu bệnh và hóa mô miễn dịch của vùng trong hốc mũi là: Carcinoma tế bào gai không sừng hóa. Bệnh nhân được phẫu thuật cắt khối u trong hốc mũi qua nội soi mũi và mở lại sọ trán để tái tạo nền trước theo kỹ thuật nhiều lớp cải tiến, sử dụng 2 vạt có cuốn, sau đó được hội chẩn điều trị với chuyên khoa ung bướu để xạ trị. Sau phẫu thuật 3 tháng chưa thấy xuất hiện lại triệu chứng chảy dịch mũi, lớp tái tạo sàn sọ đúng vị trí (hình 3 ).

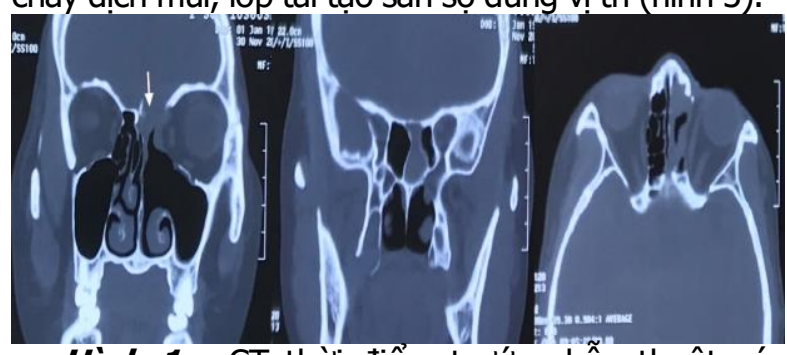

Hình 1a: CT thời điểm trước phẫu thuâtt vá sàn sọ lần thứ 4 cho thấy hình ảnh khuyết xương lớn vùng mảnh sàng và hố sàng bên trái, đậm độ dịch tại vùng sàng và xoang bướm $(T)$, thay đổi cấu trúc hốc mũi xoang hàm sàng $(T)$ sau phẫu thuật trước đó.

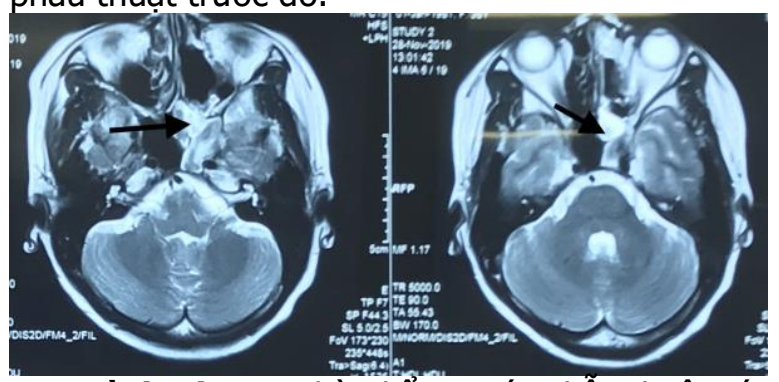

Hình 1b: MRI thời điểm trước phấu thuật vá sàn sọ lần thứ 4 cho thấy dò DNT qua sàn sọ tại chỗ khuyết và DNT dò vào trong xoang bướm (T).

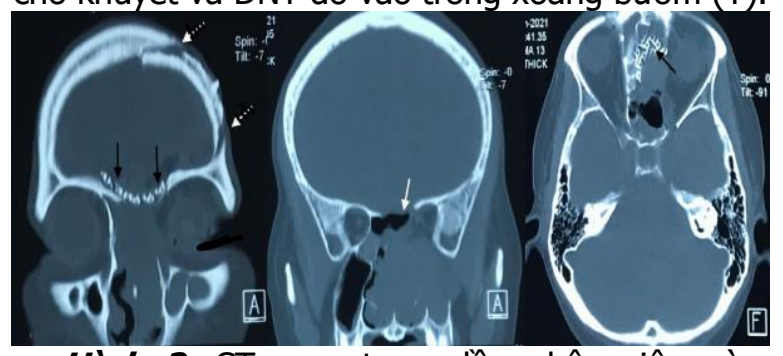

Hình 2: CT scan trong lần nhập viện này. Thấy được đường mổ sọ trán 2 bên (mũi tên đút đoạn), đậm độ mô mềm trong hốc mũi nghĩ 
nhiều là máu đông, phân biệt với tổn thương choán chỗ, thấy được hình ảnh mất liên tục xương sàn sọ (mũi tên trắng) và miếng titan của lần phẫu thuật trước không che kín khuyết tổn (mũi tên đen).

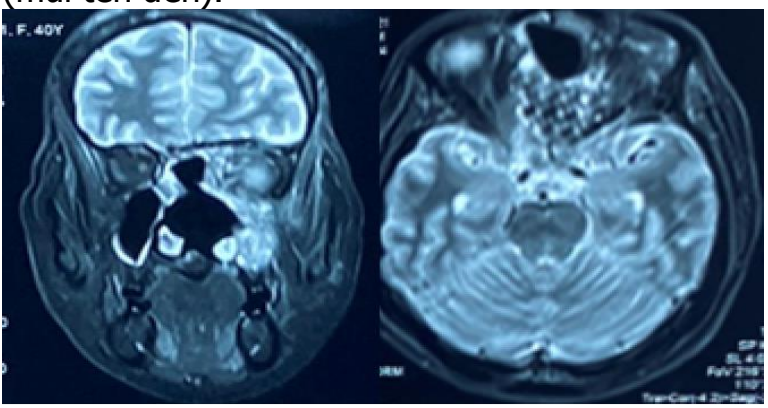

Hình 3: MRI sau tái tạo sàn sọ 3 tháng

\section{BÀN LUÂ̂N}

Nguyên nhân gây chảy DNT qua mũi thường gặp nhất là chấn thương do tai nạn hoặc sau phẫu thuật. Những trường hợp chảy DNT qua mũi sau phẫu thuật mũi xoang thường là những khuyết tổn nhỏ và tỷ lệ tái tạo khuyết tổn thành công cao từ lần phẫu thuật đầu tiên [2]. Trường hợp ca lâm sàng chúng tôi báo cáo ở đây xuất hiện chảy DNT qua mũi sau phẫu thuật nội soi mũi xoang. Tuy nhiên bệnh nhân đã được phẫu thuật vá sàn sọ nhiều lần bằng nhiều phương thức khác nhau nhưng vẫn tái phát. Ở lần phẫu thuật này, khi lấy mầu mô trong hốc mũi thử GPB và hóa mô miễn dịch xác định tổn thương ác tính: carcinoma tế bào gai biệt hóa trung bình. Đây có thể là nguyên nhân tiềm ẩn của sự lành thương kém và khuyết tổn lớn ở sàn sọ trước. Do đó, trong những trường hợp chảy DNT tái phát nhiều lần sau phẩu thuật tái tạo sàn sọ, chúng ta cần phải tìm nguyên nhân, vị trí, kích thước của khuyết nền sọ và sử dụng phương pháp tái tạo nền sọ phù hợp.

CT scan giúp xác định vị trí khuyết tổn xương tại sàn sọ. MRI hỗ trợ xác định nếu có thoát vi não đi kèm. Phẫu thuật vá sàn sọ được thực hiện để ngăn chặn biến chứng xảy ra. Vì kích thước khuyết sàn sọ lớn, phẫu thuật mở sọ của ngoại thân kinh được kết hợp với phẫu thuật nội soi qua mũi tái tạo sàn sọ bằng nhiều lớp với $k y ̃$ thuật cải tiến, kỹ thuật sandwich cải tiến:

a. Lớp 1: dùng vạt cân cơ sọ trán có cuống được tạo ra trong lúc phẫu thuật mở sọ trán, che phủ nền sọ trước khuyết đến phần xương mảnh vuông xoang bướm (planum sphenoid) giới hạn khuyết phía sau và cố định bằng keo sinh học.

+ Gây tê bằng hỗn hợp dung dịch Adrenalin $1 / 100.000$ và Lidocain $0,5 \%$.
+ Rạch da ngay trước lỗ ống tai ngoài bệnh nhân khoảng $1 \mathrm{~cm}$, đi từ bờ trên cung gò má hướng lên trên theo đường chân tóc trán hai bên, bóc tách vạt da xuống ngang bờ trên ổ mắt 2 bên bảo tồn phần cân mạc sọ trán.

+ Tách vạt cân sọ trán giữ cuống vạt đến ngang bờ trên ổ mắt 2 bên.

b. Lớp 2: dùng lưới titanium che phủ phía trên vạt cân sọ trán đúng vị trí nền sọ khuyết, cố định bằng đinh vặn trên trần hốc mẳt nhẳm gia cố phần xương khuyết tránh thoát vị não sau phẫu thuật.

c. Lớp 3: màng não khuyết do u xâm lấn đã được cắt bỏ, dùng cân cơ thái dương tái tạo lại, giúp đóng kín màng não khuyết và tránh tiểp xúc giữa mô não và lưới titanium (titanium mesh).

d. Lớp 4: dùng vạt cuốn mũi dưới và vạt vách mũi xoang bên trái vì trường hợp này khối u làm tổn thương vách ngăn mũi giúp cho niêm mạc nền sọ trước mau hồi phục hơn hạn chế các biển chứng rò dịch não tủy hay viêm màng não sau mổ.

Kết quả phẫu thuật sau 3 tháng, không ghi nhận tình trạng chảy dịch tái phát và các lớp tái tạo đúng vị trí. Khi đã xác định được bệnh lý ác tính, bệnh nhân được kết hợp điều trị ung bướu sau đó.

\section{KẾT LUẬN}

Trường hợp chảy DNT tái phát nhiều lần không tương xứng với nguyên nhân được biết trước đó có thể do tồn tại một yếu tố khác chưa kịp nhận diện. Để điều trị những trường hợp này cần tìm những nguyên nhân tiềm ẩn và sử dụng phương pháp tái tạo nền so cải tiến 2 vạt có cuốn để tái tạo sàn sọ khuyểt rộng như một lựa chọn thích hợp.

\section{TÀI LIÊU THAM KHẢO}

1. Cansiz Harun, Cambaz Bülent, Papila Irfan, Tahami Rauf, Güneş Muammer \%] The Journal of craniofacial surgery (1998), Use of free composite graft for a large defect in the anterior skull base. 9 (1), 76-78.

2. Hegazy Hassan M, Carrau Ricardo $L$, Snyderman Carl H, Kassam Amin, Zweig Julie $\%]$ The Laryngoscope (2000), Transnasal endoscopic repair of cerebrospinal fluid rhinorrhea: a meta-analysis. 110 (7), 1166-1172.

3. Kim-Orden Natalie, Shen Jasper, Or Maya, Hur Kevin, Zada Gabriel, Wrobel Bozena \%] Allergy, Rhinology (2019), Endoscopic endonasal repair of spontaneous cerebrospinal fluid leaks using multilayer composite graft and vascularized pedicled nasoseptal flap technique. 10, 2152656719888622.

4. Zlab Mark K, Moore Gary F, Daly David T, Yonkers Anthony J \%] Ear, nose, journal throat (1992), Cerebrospinal fluid rhinorrhea: a review of the literature. 71 (7), 314-317. 